\title{
41. DEEP-SEA DRILLING OFF THE CALIFORNIAS: IMPLICATIONS OF LEG $\mathbf{3}^{1}$
}

\author{
Robert S. Yeats, Department of Geology, Oregon State University, Corvallis, Oregon \\ and \\ Bilal U. Haq, Woods Hole Oceanographic Institution, Woods Hole, Massachusetts
}

\section{INTRODUCTION}

Continuously cored holes drilled at seven sites off the coasts of Alta and Baja California offer the perspective of stratigraphic sections at the margin of the North American continent (Fig. 1). These holes fill the gap between well-mapped sequences along the coastal and near-shore regions of the Californias and DSDP core holes on the Pacific plate far to the west of the continent. The core holes are particularly useful because the seven drilling sites are relatively well-surveyed, and discontinuities in the cores can be correlated with unconformities in seismic-reflection profiles. Sites 467 , 468 , and 469 can be placed in a regional framework for the southern California borderland based upon work by the U.S. Geological Survey together with studies done at the University of Southern California and Scripps Institution of Oceanography. Sites 470, 471, 472, and 473, off Baja California, are in a region under extensive study by Oregon State University and the Dirección General de Oceanografía of Mexico, study that supplements earlier investigations done at Scripps and elsewhere.

Despite the work done up to now, including Leg 63, we find ourselves with more questions than answers. Leg 63 did not resolve the major controversies regarding the origin and structural evolution of the southern California borderland. The structure southwest of Baja California is much more complex than believed previously, and the existing survey trackline density is insufficient to resolve the uncertainties. Furthermore, Leg 63 did not achieve the broad paleoenvironmental objective of finding clues to the Neogene oceanographic history of the California Current system due to the poor preservation of the microfossil record at most sites. For these reasons, Leg 63 broke less new ground than anticipated; consequently, this synthesis is a progress report that points out problems more than it comes to conclusions.

The tectonic discussion is divided into three geographic regions: (1) the southern California borderland, with Sites 467, 468, and 469, (2) the Guadalupe Arrugado immediately south of the borderland, with Site 470, and (3) southern Baja California, with Sites 471, $\mathbf{4 7 2}$, and 473 (concentrating on Site 471 ). A brief account of the paleoenvironmental implications of Leg 63 follows the discussion of tectonics.

\footnotetext{
${ }^{1}$ Initial Reports of the Deep Sea Drilling Project, Volume 63.
}

\section{SOUTHERN CALIFORNIA BORDERLAND}

\section{Sediment Accumulation Rates: Comparison with Onshore Basins}

Subsidence rates of Miocene to Quaternary strata in the Ventura, Los Angeles, Soledad, and Ridge basins were published by Yeats (1978). These rates, determined for onshore sections, are not directly comparable to sediment accumulation rates because they are affected by changes in water depth from 1500 meters to near sea level for Pliocene and Pleistocene strata. But all three DSDP borderland sites are in water depths greater than 1500 meters so that a change of water depth would have less significance in the borderland sites than in the onshore basins. For example, middle Miocene to Pleistocene benthic foraminifers at Site 468 all indicate a lower bathyal biofacies (Blake, this volume). Subsidence rates onshore are based upon radiometrically calibrated local benthic foraminiferal stages that are inherently timetransgressive with respect to coccolith zones (Crouch and Bukry, 1979), although Arnal (1980) argued that the overlap between benthic foraminiferal stages and coccolith zones is considerably less than that suggested by Crouch and Bukry (1979). Arnal suggested that the overlap may be in part caused by lack of precision of coccolith zones in temperate latitudes.

Despite these problems, comparisons are possible. For the last $4 \mathrm{~m} . \mathrm{y}$., subsidence rates in the onshore basins show a sharp increase (Fig. 2), including an order of magnitude increase in the Ventura basin attributed by Yeats (1978) to horizontal loading of the crust near the big bend in the San Andreas fault. Sedimentation rates at the borderland sites (Fig. 2), far from the San Andreas fault, show no such increase. All three sites are characterized by relatively low, locally discontinuous, highly variable rates of sedimentation during the last 4 m.y. At Site 467, sediment accumulation rates showed a moderate increase from 5 to $2 \mathrm{Ma}$, then a decrease for the last 2 m.y. The increase in the Pliocene reflects an increase in the supply of terrigenous material to the site; evidence for this is the change in the nature of organic material from a marine facies upsection to a mixed marine-terrestrial facies (Simoneit et al., this volume). Sediment accumulation rates also increased for the same time interval at Site 173 at the foot of the California continental escarpment near latitude $40^{\circ} \mathrm{N}$ (von Huene and Kulm, 1973). The increase at Site 173 was attributed by Ingle (1973) to an increase in terrigenous sediments related to an increase in tectonic activity, as documented in coastal California (Ingle, 1980); a similar explanation 


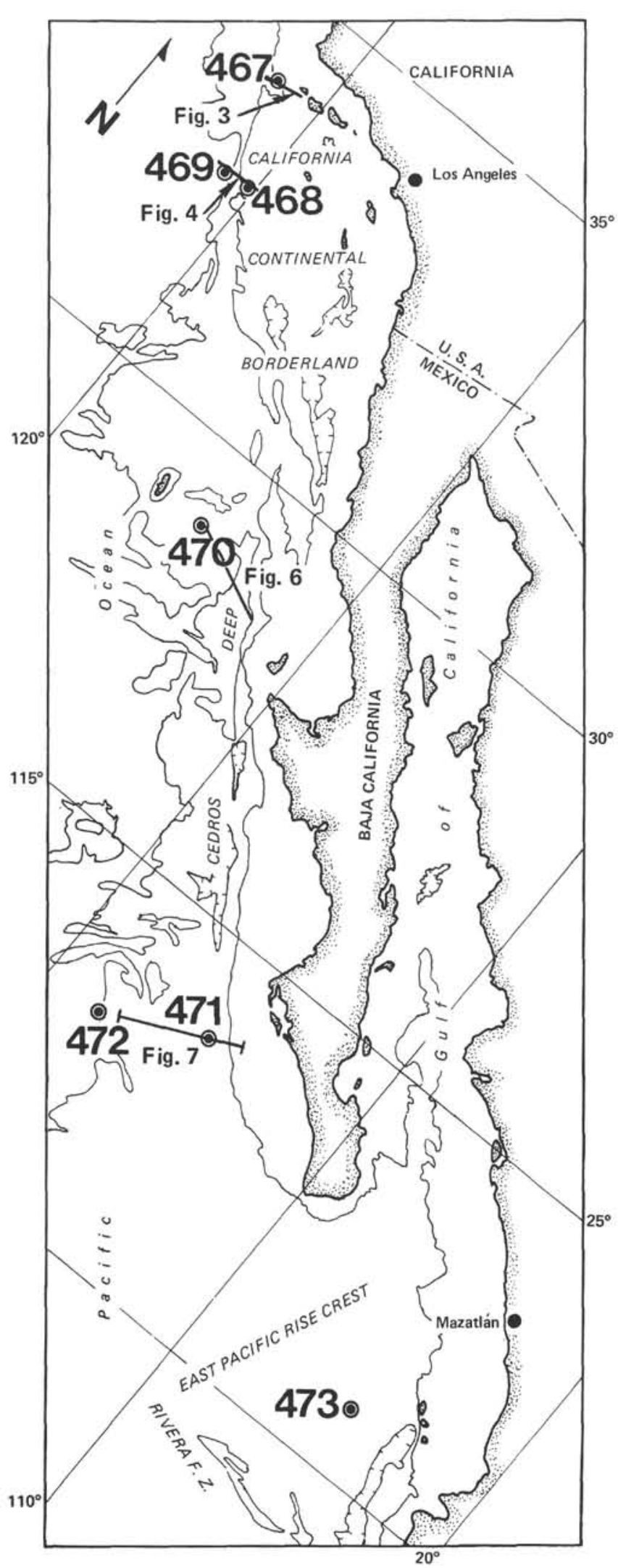

Figure 1. Location of DSDP Leg 63 sites. (Note locations of seismicreflection profiles shown as line drawings in Figs. 3, 4, 6, and 7.)

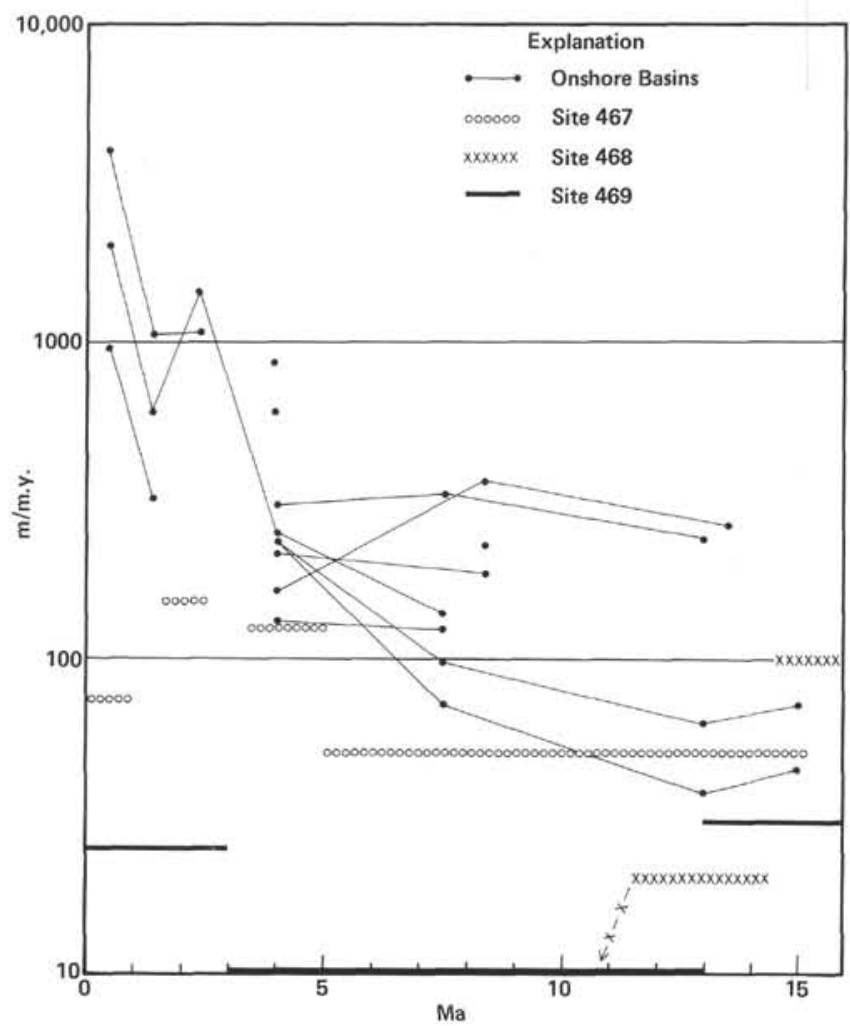

Figure 2. Comparison of sediment accumulation rates in southern California borderland Sites 467, 468, 469 and subsidence rates of coeval strata in onshore Ventura and Los Angeles basins. (Onshore rates from Yeats [1978].)

is suggested for the increase at Site 467 . The decrease in sedimentation rates at Site 467 during the last 2 m.y. and at Site 468 for the last 11.5 m.y. may be due to the development of offshore topographic barriers such as the northern Channel Islands, isolating the sites from continental source areas.

In contrast to the variability of rates in the late Neogene, sediment accumulation rates for the middle Miocene, 13 to $16 \mathrm{Ma}$, are very similar at the DSDP sites and the onshore Ventura basin-somewhat less than 100 $\mathrm{m} / \mathrm{m}$.y. (Fig. 2). The onshore rates less than $100 \mathrm{~m} / \mathrm{m}$.y. in this time interval are for the fine-grained, relatively organic Monterey Shale of the upper Ojai Valley, Sulphur Mountain, and Sespe Creek areas of the Ventura basin. The other two onshore rates shown are from areas in the Ventura and Los Angeles basins receiving proximal turbidite sandstones. The relatively uniform rates of sediment accumulation are characteristic of the middle Miocene silled basins that permitted deposition of prolific diatomaceous deposits undiluted by terrigenous input (Ingle, 1980). The change from uniform to more variable rates of sedimentation in Sites 467 , 468 , and 469 occurred in the late middle Miocene, 11 to 13 m.y. ago; the change occurred at about the same time as a major unconformity in the outer southern California borderland mapped by Crouch (1979), suggesting that the change may have been influenced by tectonics. At Site 469, the terrigenous component (clay, silt, and 
sand) of the sediments is greatly reduced upsection within the middle Miocene. Biogenic sediments deposited in the late middle and late Miocene are surprisingly free of terrigenous components, considering the proximity of Site 469 to the Patton Escarpment. The reduction in terrigenous contribution may occur at a slightly younger horizon at Site 468 than 469 . In both instances, the reduction in terrigenous contribution may be caused by the cut-off of a continental source of sediments by the formation of intervening borderland basins and ridges, including the Patton Ridge.

It is clear, however, that borderland topography began to develop prior to the middle Miocene. Local blueschist basement detritus occurs in strata as old as early Miocene. Crouch (1979) pointed out the presence of an angular unconformity between Oligocene(?) and lower Miocene strata, and he argued that the Patton Ridge may have been a topographic high prior to the late Miocene. A multichannel seismic-reflection profile at Site 467 (Fig. 3) shows an angular unconformity as old as 16 to 16.5 m.y. separating the sequence cored at the site from an underlying, well-bedded sequence with steeper dip (Crouch et al., 1978).

\section{Significance of Volcanic Rocks}

A pumiceous lapilli tuff alternating with chalk, limestone, and claystone deposited in the late middle and early late Miocene (10-12.5 Ma) was cored at Site 467. The age of this volcanic unit is younger than the age generally assigned to volcanism in the southern California borderland and adjacent coastal basins. Radiometric ages in the borderland volcanics range from 13 to $24 \mathrm{~m}$.y. with most ages in the range of 13 to 16 m.y.; the younger volcanics are interbedded with middle Miocene marine strata, on the basis of local California benthic foraminiferal stages. Vedder and others (this volume) identify other areas in the borderland where volcanic constituents occur in post-middle Miocene strata. These include tuffaceous sandstone in a deep-test well in the Santa Barbara Channel west of Pt. Concep- tion, vitric tuff laminae and volcaniclastic sandstone and conglomerate in dart cores from borderland ridges, amygdaloidal basalt $6.4 \pm 0.5 \mathrm{~m}$.y. of age from a knoll west of Northeast Bank, and volcanic and volcaniclastic rocks on Santa Catalina and San Clemente islands. Vedder and others (this volume) conclude that in the southern California borderland, volcanism continued into the late Miocene and locally into the early Pliocene. This is in contrast to the onshore Ventura and Los Angeles basins to the east, where post-middle Miocene strata are nonvolcanic except for thin layers of vitric ash.

Intermediate-composition volcanic rocks occur at Site 468 on Patton Ridge, within $20 \mathrm{~km}$ of the site of the fossil trench between the Farallon and North American plates. Vedder and others (this volume) conclude that this is probably too close for these volcanics to have been derived from a subduction zone. They suggest that the volcanics are related to the ancestral East Pacific Rise, as suggested earlier by Yeats (1968).

\section{Implications for Tectonics of the Oceanic Pacific Plate}

Except for the terrigenous and volcanogenic contributions to the sediment column, Site 469 has many characteristics typical of oceanic crust sites found elsewhere on the west flank of the East Pacific Rise, including metalliferous sediment overlying rather typical ocean-floor pillow basalt with quench textures. The biostratigraphic age of the basement at this site is $17 \pm 0.5$ m.y. With a nominal basement depth of 4200 meters, the calculated age of the basement at Site 469 should be about $22 \mathrm{~m}$.y. old, using the age-depth curve of Sclater and others (1971). Magnetic anomalies at Site 469 are not lineated and thus preclude a basement age determination using this method. However, an extrapolation eastward of magnetic anomalies south of the Murray fracture zone, identified as far east as $123^{\circ} \mathrm{W}$ (Atwater, 1970 ), results in a rather tenuous age determination of 20 m.y.

Thus the paleontological age does not agree closely with any of the other methods used to date oceanic

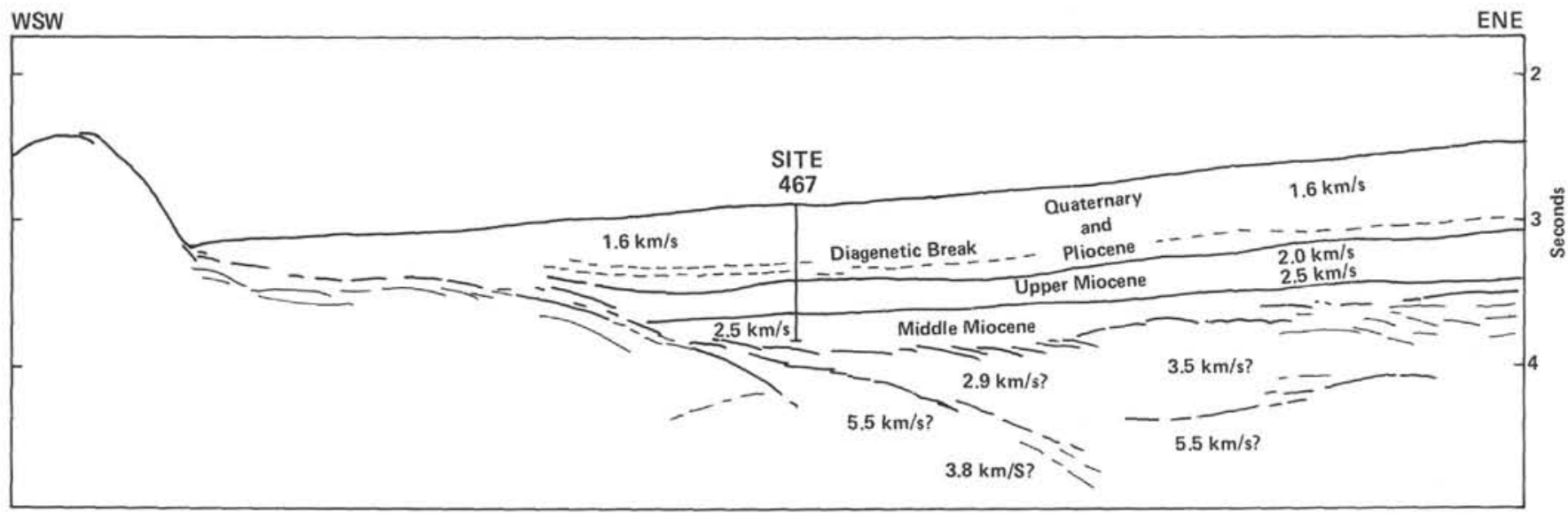

Figure 3. Line drawing of multichannel seismic-reflection profile recorded by U.S. Geological Survey vessel S. P. Lee and published by Crouch and others (1978). (This profile appears as fig. 3 of Site 467 report. Stacking velocities and correlation of the reflection profile with drilling results were determined by J. K. Crouch [personal communication, 1978].) 
crust. This may be due to the fact that the present altitude of the oceanic crust has been influenced by the adjacent continental margin (cf., Fig. 4)-once a subducting margin, later a transform margin, and now essentially a passive margin. The present transform boundary is the San Andreas fault, which no doubt has some influence on tectonism along the margin.

\section{SITE 470 AND THE GUADALUPE ARRUGADO}

Site 470 and the Experimental Mohole are located on the abyssal seafloor west of Baja California in a region characterized by north-trending magnetic anomalies midway between Anomalies 5 and 6 (Atwater, 1970), about $15 \mathrm{~m} . \mathrm{y}$. in age. The area was called the Guadalupe Arrugado (i.e., rolling plain) by Krause (1965), and its topographic grain is north-south, like that of the magnetic anomalies (Fig. 5). The site lies between two prominent west-trending features that are probably fracture zones (Calderon, 1978). These are Popcorn Ridge (Fig. 5), which separates the Guadalupe Arrugado from the southern California borderland province, and Shirley Trough to the south, an eastern extension of the Molokai fracture zone (located at $28^{\circ} \mathrm{N}, 117^{\circ} \mathrm{W}$, though not contoured on Fig. 5). The Guadalupe Arrugado is separated from the Baja California continental margin by the Cedros Deep.

The age of sediments at the basement contact is $\mathbf{1 5 . 5}$ $\pm 0.5 \mathrm{~m}$.y., on the basis of nannofossil evidence. This is consistent with the $15.5-\mathrm{m} . \mathrm{y}$. basement age estimated using magnetic anomalies, and with the $15 \pm 7-\mathrm{m} . \mathrm{y}$. $\mathrm{K}$-Ar date of Krueger (1964) from the Experimental Mohole. The basement at Site 470 is about 3720 meters below sea level, resulting in a predicted basement age of $15 \mathrm{~m} . \mathrm{y}$. using the subsidence curve of Sclater and others (1971).

A comparison of basement ages at Sites 469 and 470 indicates that the Sclater subsidence-curve age of basement at Site 470 is in agreement with the paleontological age, but the subsidence-curve age at Site 469 is not. At Site 469 , the basement surface slopes toward the continent in the direction of decreasing age (Fig. 4), the opposite effect predicted by the Sclater age-depth relationship. In contrast, at Site 470 , the basement surface rises gradually toward younger crust (as expected) and drops abruptly into the Cedros Deep along great normal faults, three of which are shown in Figure 6. Perhaps Site 469 is affected by the vertical load of the adjacent continent and is thus too deep for its age. Site 470 is farther away from the continent and is separated from it by large normal faults; hence, the site is more likely to be in isostatic equilibrium.

Sediment thickness across the Guadalupe Arrugado increases gradually from Site 470 eastward to the Cedros Deep, but there are no abrupt increases across the normal faults (Fig. 6). The normal faults could have been produced by flexing of oceanic lithosphere as it was loaded by the adjacent continent, but if so, it is surprising that only east-facing scarps are seen in Figure 6. An alternative possibility is that the normal faults and the Cedros Deep itself are parts of a northwest-trending

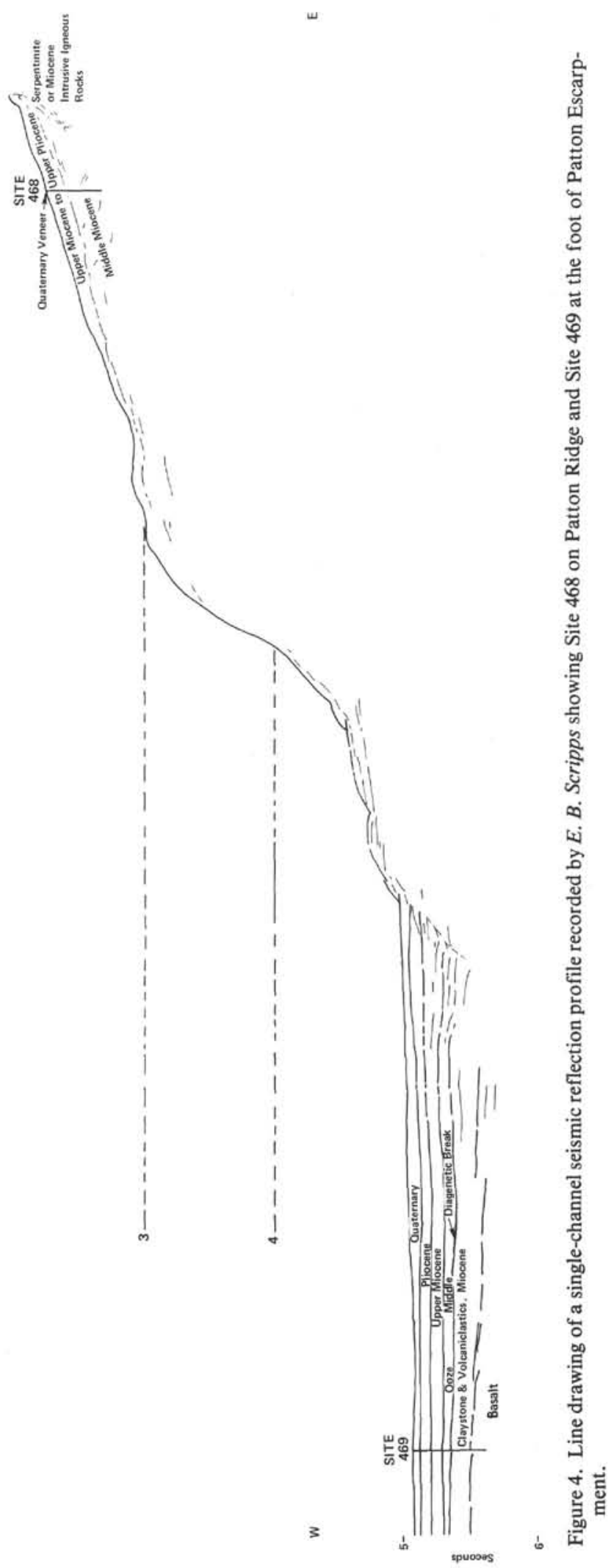

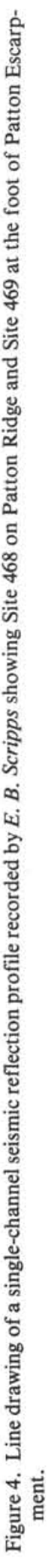




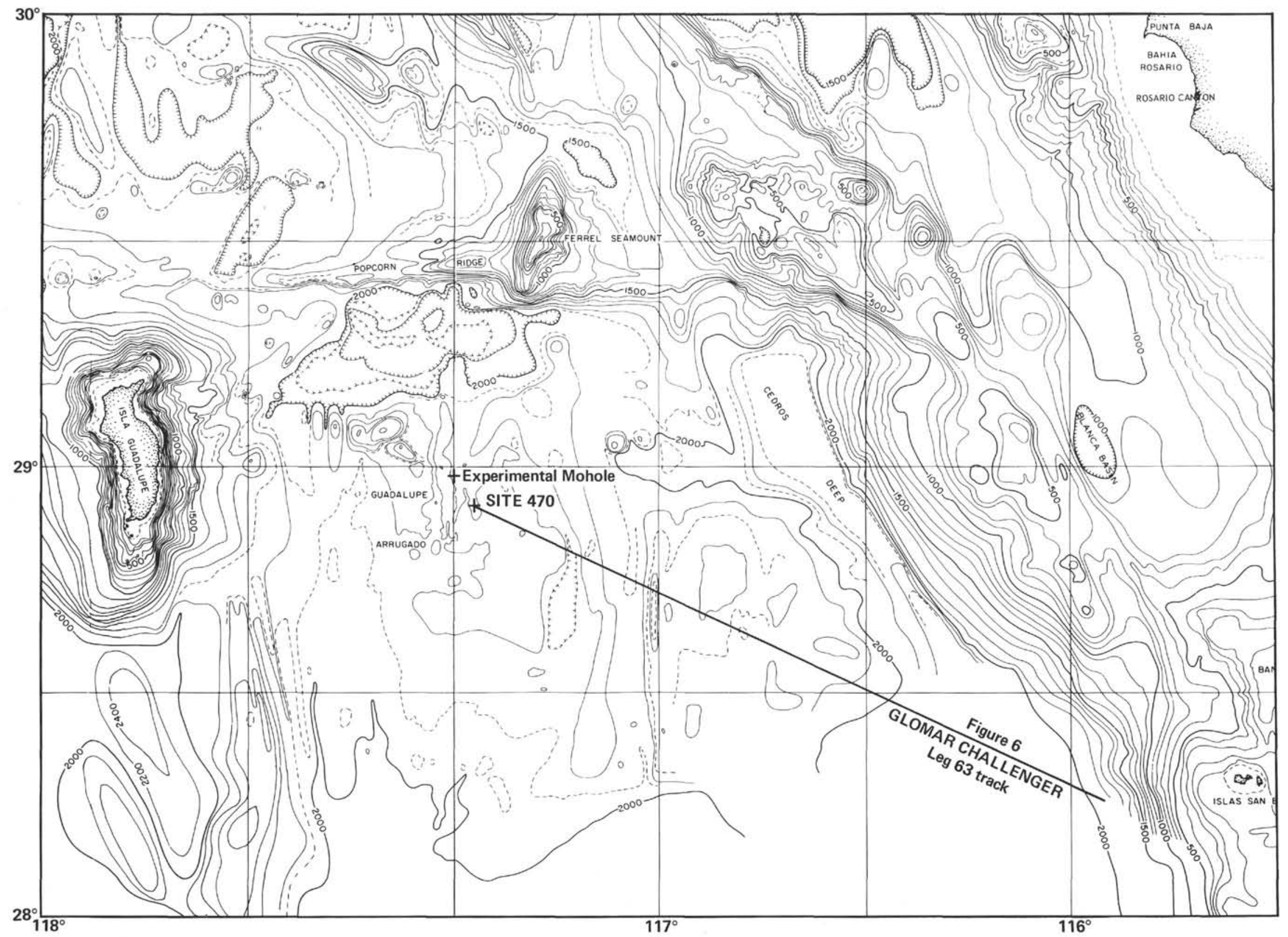
Straight line locates that part of Leg 63 track shown in Fig. 6.) 


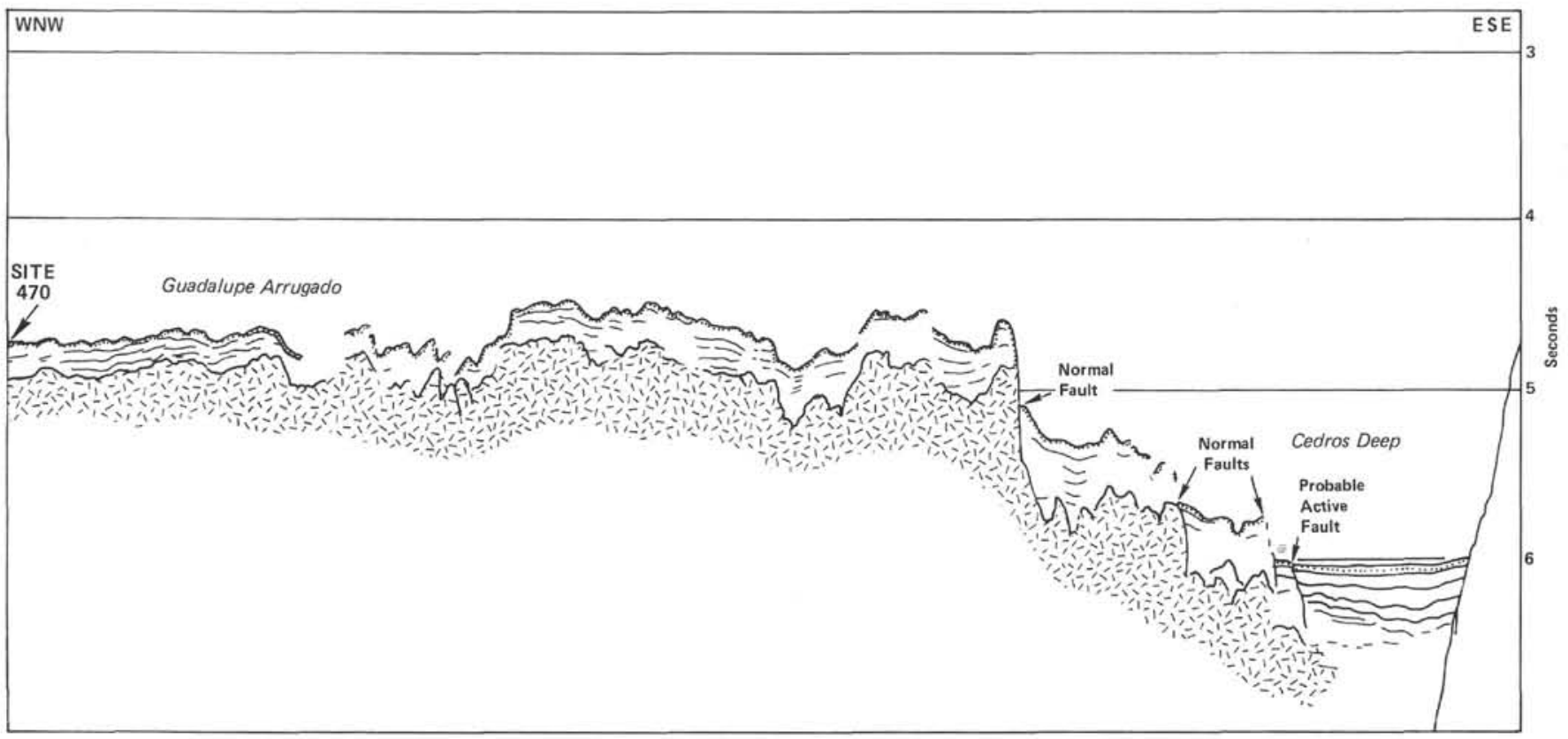

Figure 6. Line drawing of Glomar Challenger Leg 63 airgun profile from Site 470 to Cedros Deep. (Location of profile on Fig. 5.)

strike-slip fault system related to the Tosco-Abreojos fault zone of Spencer and Normark (1979) on the Baja California continental margin. This area is within the uncontoured portion of Figure 6 . New bathymetry and more refined contouring are needed to determine whether the normal faults strike northwest, parallel to the Cedros Deep, or north, parallel to the magnetic anomalies. A west-facing scarp at longitude $117^{\circ} \mathrm{W}$, latitude $28^{\circ} 20^{\prime}$ to $28^{\circ} 50^{\prime} \mathrm{N}$ mapped by Krause (1965) trends north and appears to be unrelated to the Cedros Deep. Possibly the normal faults are younger than most of the sediments. Figure 6 shows a small, east-facing fault scarp cutting flat-lying sediments of the Cedros Deep; this scarp shows prominently on the depth-recorder and airgun profiles and must have been formed in the late Quaternary. The absence of abrupt thickening of sediments on the downthrown side of the faults suggests that the faults formed after accumulation of most of the sediments.

\section{SOUTHERN BAJA CALIFORNIA}

\section{Magdalena Fan and Site 471}

The greatest structural surprise of Leg 63 was the discovery that the sediments immediately overlying basement at Site 471 contain microfossils that are 14.5 $\pm 0.5 \mathrm{~m} . y$. in age, whereas a straightforward eastward extrapolation of magnetic anomalies had predicted a basement magnetic age of $11 \mathrm{~m}$.y. (Chase et al., 1970). However, the Sclater subsidence-curve age of basement at 3857 meters is $16 \mathrm{~m} . \mathrm{y}$., which is in reasonable agreement with the paleontological age, if the effect of a load of 740 meters of sediment and the edge effects of adjacent continental crust are taken into account. Clearly, the assumption of Chase et al. (1970) and virtually all other workers that magnetic anomalies in this region become younger eastward to the foot of the continental slope is wrong at Site 471.
Site 471 was drilled on a broadly convex feature called here the Magdalena fan (Fig. 7). Over half of the sediment section, from about 304 meters to 741.5 meters, was deposited in about $1.5 \mathrm{~m} . \mathrm{y}$., from 13 to 14.5 $\mathrm{Ma}$. There is a drastic drop in sediment accumulation rates from $250 \mathrm{~m} / \mathrm{m} . \mathrm{y}$. for the older sequence to 50 $\mathrm{m} / \mathrm{m}$.y. for the younger sequence. Deposition of sediments in the last 8 m.y. occurred even more slowlyabout $20 \mathrm{~m} / \mathrm{m}$.y. The Magdalena fan is, therefore, a fossil feature, not necessarily related to the present topography.

There are two tectonic questions raised by the results at Site 471 . First, why is the oceanic crust at the site 4 m.y. older than expected? Second, why did the sediment accumulation rate decrease so abruptly $13 \mathrm{Ma}$ ?

Haq, Yeats and others (1979) suggest that Site 471 may have been drilled on a fragment of the Farallon plate trapped west of southern Baja California. Previous studies of the magnetic anomalies off southern Baja California (e.g., Chase et al., 1970; Huehn, 1977; Coperude, 1978) indicate that magnetic anomalies become progressively younger eastward, and that they change from a northerly to a north-westerly strike as they become younger. The counterclockwise rotation to a strike parallel to the continental slope was explained by Menard (1978) as being caused by the difference in density at the trench boundary between colder lithosphere southward and hotter, younger lithosphere northward. The colder, more southerly lithosphere would be pulled downward by gravity faster than the hotter lithosphere to the north. Accordingly, the magnetic stripes would swing toward parallelism with the trench by a "drogue" effect.

But as the Farallon plate disappeared down the subduction zone, it began to break up, calving off a separate fragment called here the Magdalena plate and forming a new spreading center southeast of Site 471 by $10 \mathrm{Ma}$ (Fig. 8B). If this interpretation is correct, then 


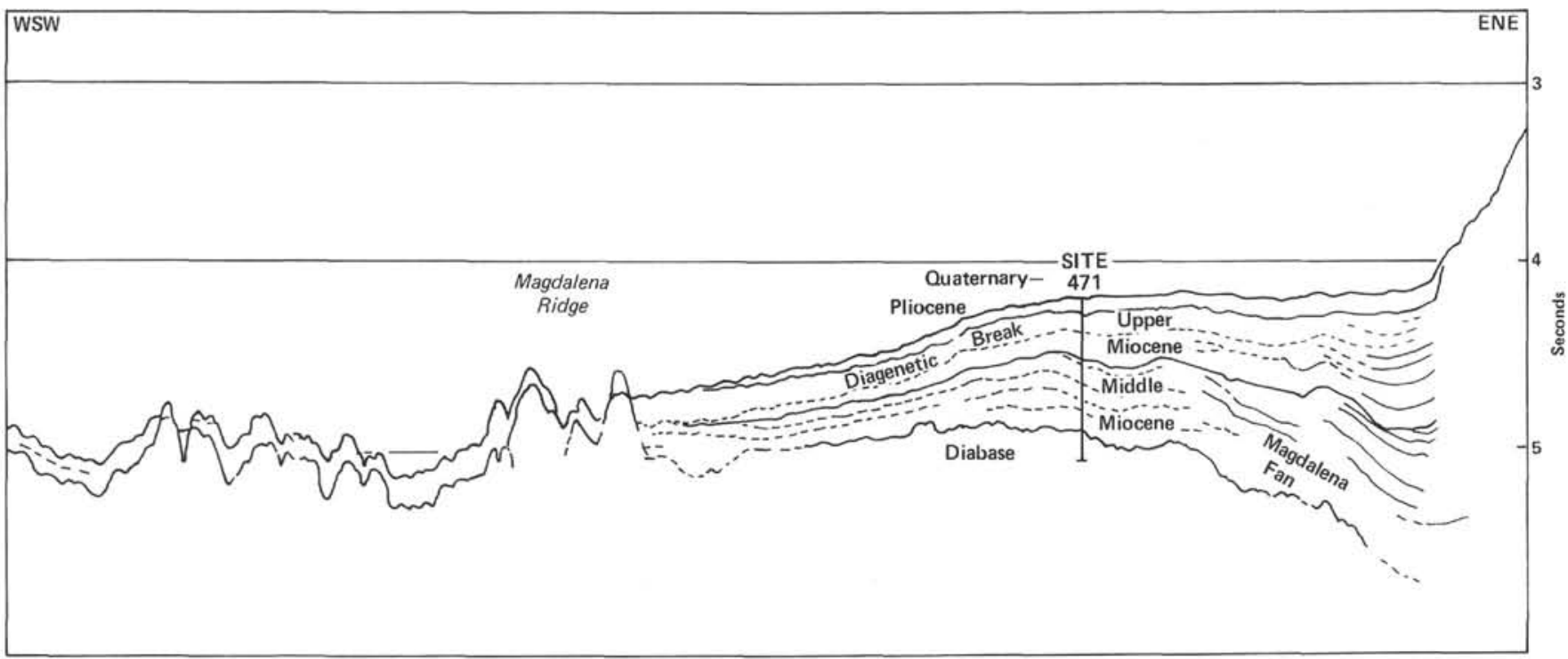

Figure 7. Line drawing of Glomar Challenger Leg 63 airgun profile approaching and departing Site 471. (Magdalena Ridge is suggested by Ness and others [this volume] to be a fragment of the East Pacific Rise that was abandoned 13.7 Ma, trapping a piece of Farallon plate on which the Magdalena fan was deposited.)

magnetic anomalies 11 to 15 m.y. old should be symmetrical about an abandoned rise crest somewhere between Sites 471 and 472 . Ness and others (this volume) addressed this problem by comparing the Glomar Challenger magnetic anomaly profile with magnetic anomaly profiles obtained by Oregon State University and Dirección General de Oceanografía and by attempting to correlate all profiles with synthetic anomalies generated using the magnetic anomaly time scale NLC-80 (Ness et al., 1980). They find very good correlation between magnetic anomalies on the western ends of DSDP tracklines approaching and departing Site 472 and between those anomalies and crust of 14 to $15 \mathrm{~m}$.y. of age as indicated on scale NLC-80. On the other hand, the eastern half of the DSDP track between Sites 471 and 472 is difficult to correlate both with synthetic anomalies and with measured anomalies immediately to the south. But Ness and others (this volume) find a mirror symmetry of magnetic anomalies along the DSDP track between Sites 471 and 472 , which suggests the presence of a fossil rise crest of 13.7 m.y. of age that they call the Magdalena Ridge (Fig. 7). Of necessity they then explain the lack of correlation between the eastern half of this track near Site 471 and the track between Sites 472 and 473 by a fault. As they emphasize, this solution is rather ad hoc, because the structural complexity of the area is apparently at a finer scale than the density of tracklines used in their study. The ridge, however, appears to be the most reasonable explanation for the anomalously old crust at Site 471.

The structure is too complex to map details of the transfer of the Magdalena plate around Site 471 from the Farallon to the Pacific plates. Figure 8 gives a possible sequence. In Figure 8C, the Farallon plate became narrower as the rise crest approached the continent coincident with oblique subduction along the FarallonNorth American trench. Sites 471 and 472 occurred on opposite sides of that part of the rise crest called the Magdalena Ridge. By this time ( $14 \mathrm{Ma})$, the Farallon plate was already breaking up and rotating. In Figure $8 \mathrm{~B}$, a triple junction had formed as a segment of rise crest, part of the incipient Rivera Ridge, opened toward the continent. The Magdalena plate by this time had become part of the Pacific plate, and it moved to the northwest along the Tosco-Abreojos fault of Spencer and Normark (1979) and/or along a fault at the base of the continental slope west of Baja California. In Figure 8A, Baja California had separated from mainland Mexico, oceanic crust was exposed within the Gulf of California, and relative motion along the Tosco-Abreojos fault had either ceased or greatly diminished. This sequence of events is speculative, but it is consistent with Leg 63 results and with the survey results now available.

The second question has to do with why the sediment accumulation rate in the Magdalena fan dropped so abruptly $13 \mathrm{Ma}$. The Magdalena fan, as defined by the bathymetry of Ness and others (this volume), is a convex-upward topographic feature (Figs. 7, 8A) that extends southwestward from the foot of the continental escarpment from latitude $23.3^{\circ} \mathrm{N}$ to $24.1^{\circ} \mathrm{N}$. It is best delineated by the 3200-meter contour of figure 1 of Ness and others (this volume), and it is also delineated in part by the 3400-meter and 3600-meter contours west and south of Site 471 . It may be bounded on all sides by structural features. A northwest-trending ridge west of the fan on the Glomar Challenger track between Sites 471 and 472 may be the abandoned Magdalena Ridge. Next to the continental escarpment, high areas northwest and southeast of the fan may be related to the San Lázaro and Ulloa fracture zones, respectively (Ness and others, this volume; Fig. 8A, this paper).

Such a thick sequence of sediments is not generally characteristic of the foot of the continental escarpment southwest of southern Baja California. Whereas $1.6 \mathrm{~s}$ of 


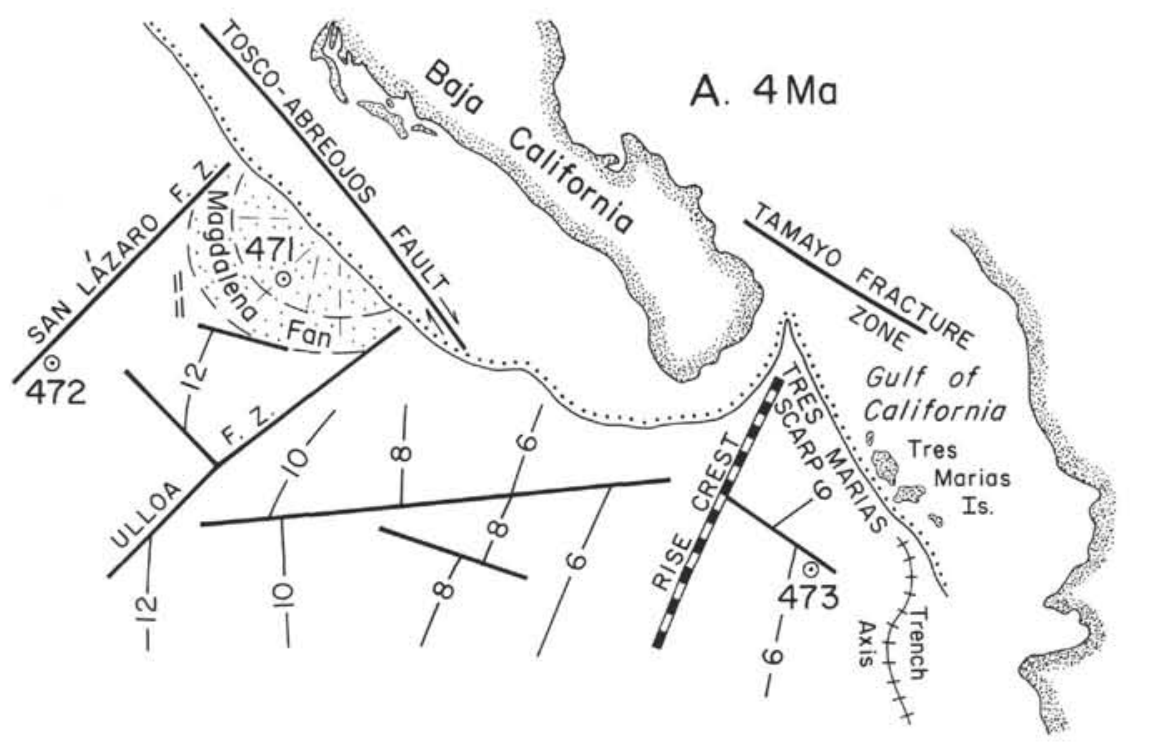

EXPLANATION
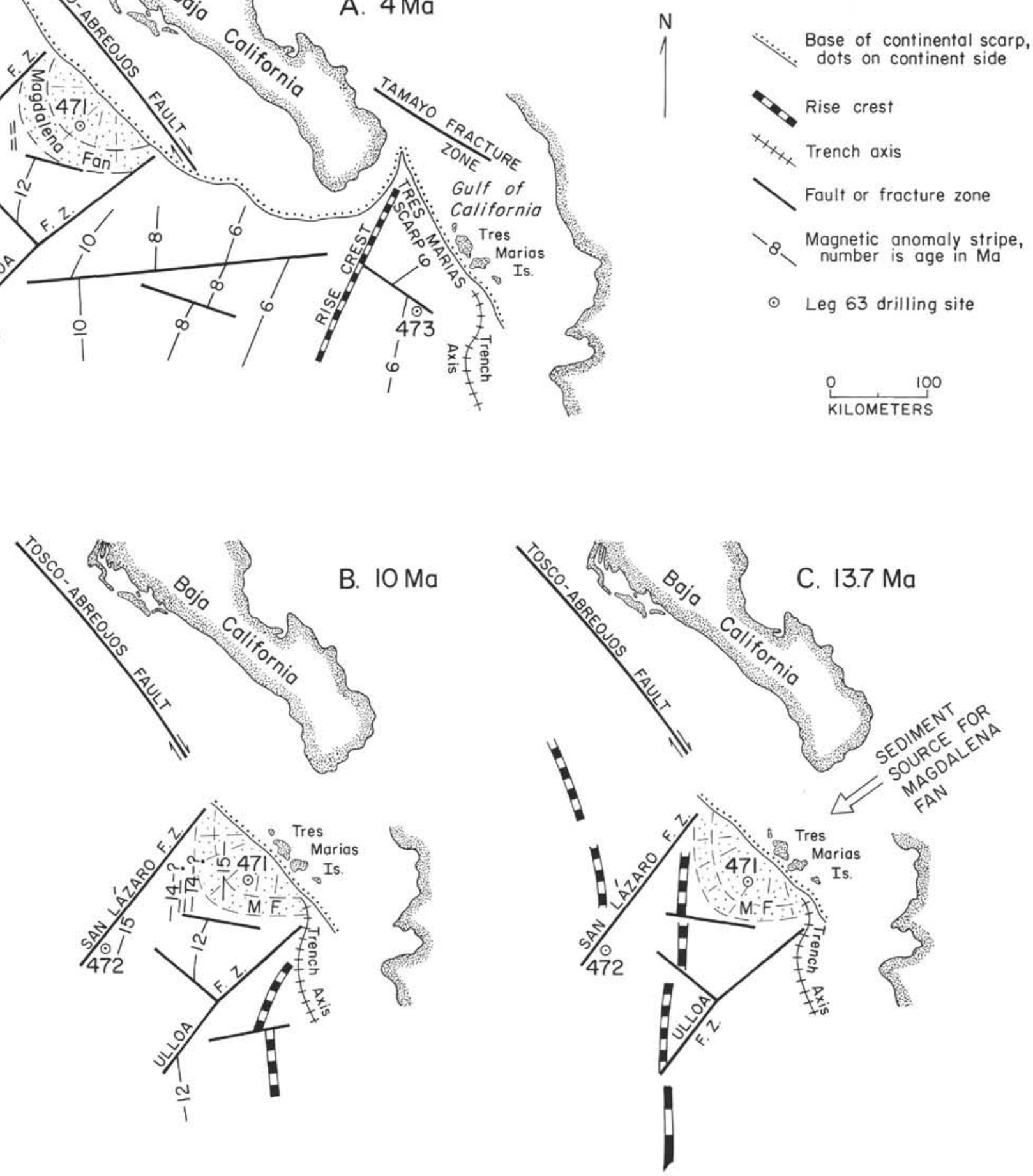

Figure 8. Palinspastic restoration of southern Baja California and vicinity at $4 \mathrm{Ma}, 10 \mathrm{Ma}$, and $13.7 \mathrm{Ma}$. (Magnetic anomalies are from Ness and others [this volume] except for 13.7-Ma rise crest position, which is in part based upon magnetic anomalies from Chase and others [1970] and Huehn [1977]. Tamayo fracture zone and fracture zones southwest of Baja California are from Ness and others [this volume]; the ToscoAbreojos fault is from Spencer and Normark [1979]. Restoration of $272 \mathrm{~km}$ right slip on the Tosco-Abreojos fault, as suggested by Spencer and Normark [1979], brings Magdalena fan-M. F. on the 10-and 13.7-Ma restorations-opposite the mouth of the Gulf of California and a potential sediment source on the Mexican mainland at $10 \mathrm{Ma}$. At 13.7 Ma, the rise crest west of Site 471 was abandoned, and by $10 \mathrm{Ma}$, the rise crest had jumped to a new position southeast of the site, trapping the Magdalena fan on a fragment of Farallon plate. The structure is too complex to resolve the details of this ridge jump with present trackline density.) 
sediments are found at the foot of the escarpment east of Site 471 , only about $0.6 \mathrm{~s}$ are found at the foot of the escarpment at $25^{\circ} \mathrm{N}$, northwest of Cabo San Lázaro (Coperude, 1978). There is no sign of the fan sequence on the Glomar Challenger Leg 54 track, which extends north-northwest about $120 \mathrm{~km}$ west of Site 471 , or on the Leg 63 track between Sites 472 and 473 , which is entirely south of $25^{\circ} \mathrm{N}$. The fan sequence is not present at Site 472. The question can therefore be rephrased: what is the source of the convex lens of sediments 13 to 14.5 m.y. of age found in the vicinity of Site 471 , and what caused the sediment accumulation rate within this lens of sediment to decrease sharply $13.5 \mathrm{Ma}$ ?

Turcotte and Ahern (1977) modeled the subsidence history of a sedimentary basin deposited directly upon cooling oceanic lithosphere. Due to isostasy, the oceanic lithosphere cools and sinks at a decelerating rate, and sediments accumulate on the subsiding lithosphere, also at a decelerating rate. Initial subsidence of sediments with density $2.4 \mathrm{~g} / \mathrm{cm}^{3}$ takes place at approximately 200 $\mathrm{m} / \mathrm{m}$.y. (Turcotte and Ahern, 1977), comparable to the sediment accumulation rates at Site 471 for the period 14.5 to $13 \mathrm{Ma}$. However, the deceleration of subsidence predicted by the isostatic cooling model is much more gradual than that observed at Site 471, suggesting that the decrease in sediment accumulation rate at Site 471 was not controlled by decelerating subsidence accompanying isostatic cooling.

The deceleration is so sharp that it seems more likely that it was due to the shut-off of sediment. Additional support for this interpretation is provided by the change in lithology: the rapidly deposited sediments older than 13 m.y. (Unit 4 of the Site 471 Report) contain thin interbeds of calcareous sandstone deposited by turbidity currents, whereas the overlying sediments contain no turbidites, and the accompanying claystone is much more siliceous than that in the older sequence. The fan sequence contains reworked Late Cretaceous and Paleocene coccoliths (Cores 39-79); reworked coccoliths are not found in overlying sediments (Bukry, this volume). There is an angular unconformity at the change in sediment accumulation rate, as seen on the Challenger airgun profile (Fig. 7).

One possible explanation for the shut-off of sediments $13 \mathrm{Ma}$ is that the fan developed when Baja California was still attached to mainland Mexico and was fed by sediments eroded from a much larger source area. This source area would have been shut off when the proto-Gulf of California formed, isolating Baja California from mainland Mexico. This explanation runs into difficulty with the age of the proto-Gulf and with the timing of early volcanism around the Gulf of California. During the late Oligocene and early Miocene, streams east of the Gulf of California flowed west at least as far as the Baja California peninsula (Gastil et al., 1979). Later, during the interval 17 to $22 \mathrm{Ma}$, a belt of mainly andesitic volcanic rocks extended parallel to the gulf with its axis close to the eastern edge of the Baja California peninsula (Gastil et al., 1979). These andesitic volcanic rocks may have been related to subduction of the Farallon plate west of Baja California. It would be difficult to imagine that the strata of the Magdalena fan, containing volcanic-poor quartzo-feldspathic sandstone, could have been derived from a large mainland source area east of this volcanic belt. An additional argument against this interpretation is the absence of a submarine canyon indenting the Pacific continental slope of southern Baja California adjacent to the Magdalena fan.

A second explanation is that the Magdalena fan was deposited next to the base of the continent escarpment west of mainland Mexico (rather than Baja California) and was translated by right-lateral strike slip to its present position off western Baja California. Spencer and Normark (1979) describe the Tosco-Abreojos fault zone on the continental margin west of southern Baja California. They suggest that this fault zone may have been a plate boundary between 4.5 and $10 \mathrm{Ma}$, accumulating $272 \mathrm{~km}$ of right slip. Figure 8 illustrates a possible tectonic reconstruction of southern Baja California with respect to the East Pacific Rise 4, 10, and 13.7 Ma, using the magnetic anomalies identified by Ness and others (this volume) and the total right-slip offset on the Tosco-Abreojos fault zone suggested by Spencer and Normark (1979). The reconstruction places the Magdalena fan in the mouth of the gulf, opposite the Tres Marias Islands, where it could well have been in the path of mainland-derived sediments.

This appears to be a better explanation except for the timing. According to Spencer and Normark (1979), right slip on the Tosco-Abreojos fault zone began 10 $\mathrm{Ma}, 3 \mathrm{~m} . \mathrm{y}$. later than the age of shut-off of sediments to the Magdalena fan. Thirteen m.y. ago was not a time of significant change in the locus or in the chemistry of circum-gulf volcanic rocks (Gastil and others, 1979). Thus this interpretation is permitted but not strongly supported by the ages of events around the gulf.

\section{NEOTECTONICS OF SOUTHWESTERN BAJA CALIFORNIA}

Part of the problem in plate reconstruction southwest of Baja California is that the Pacific margin of Baja California did not become inactive after the passage of the East Pacific Rise into the Gulf of California.

Sykes (1968) studied world seismicity for the period 1954 to 1962 and located two earthquakes immediately northwest of Cabo San Lázaro. G. Ness, O. Sanchez Z., and $\mathrm{R}$. Couch (personal communication regarding article in preparation-"Late Neogene tectonics of the mouth of the Gulf of California") have associated additional earthquakes west of Baja California with pronounced lineations in mapped free-air gravity anomalies; they have defined a zone of active faulting extending from the continental margin northwest of Cabo San Lázaro, southeast through Magdalena Bay, south down the continental slope, and terminating near $23^{\circ} \mathrm{N}$, $111^{\circ} \mathrm{W}$. Seismic-reflection profiles show west-side-up vertical displacements of the seafloor of up to several hundred meters on the continental shelf from latitude $24^{\circ}$ to $25.4^{\circ} \mathrm{N}$ (Fig. 9). This indicated to Spencer and Normark (1979) that these displacements occurred on active faults, which they mapped east of the Tosco- 


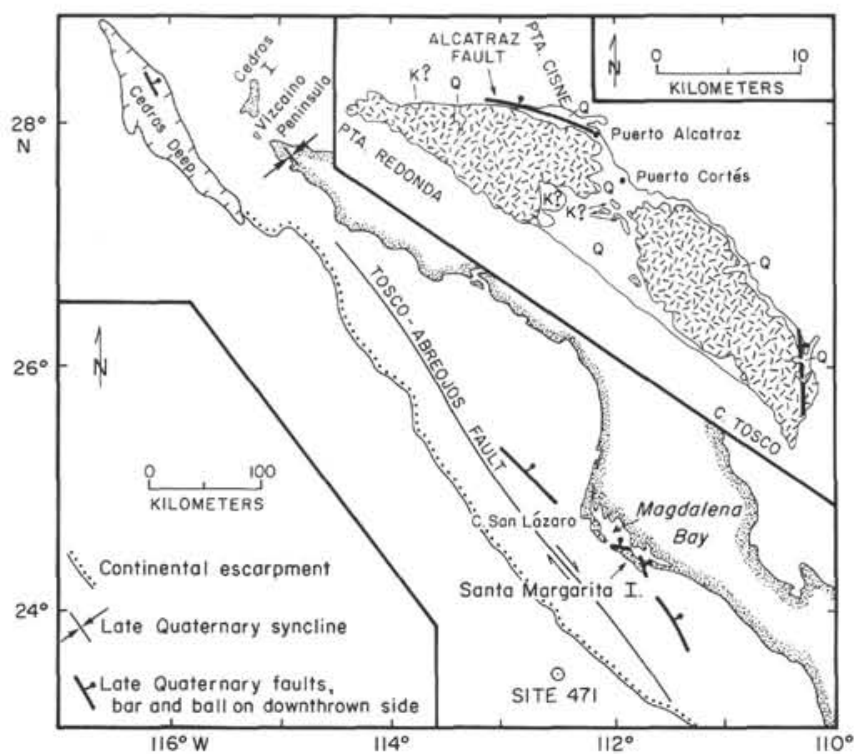

Figure 9. Neotectonic map of the continental margin west of southern Baja California. (Late Quaternary fault in Cedros Deep is from Glomar Challenger track [cf., Fig. 6]. Faults on Santa Margarita Island were mapped by the senior author. Late Quaternary faults northwest and southeast of Santa Margarita Island and ToscoAbreojos fault are from Spencer and Normark [1979]. The syncline on Vizcaino Peninsula is from Robinson [1979]. Inset map of Santa Margarita Island: shaded area = ophiolite complex; $\mathrm{K}$ ? = Late Cretaceous [?] Valle sandstone and siltstone; $\mathrm{Q}=\mathrm{Qua-}$ ternary alluvial fans and sand dunes.)

Abreojos fault zone (Spencer and Normark, 1979, fig. 1). If the faults had been connected, they would have met at Magdalena and Santa Margarita islands west of Magdalena Bay.

Several faults cut alluvial-fan deposits on the north and east sides of Santa Margarita Island (Figs. 9, 10). The most prominent of these faults passes through the fishing village of Puerto Alcatraz and is here named the Alcatraz fault (Fig. 10). The fault has a strike of $\mathrm{N} 75^{\circ} \mathrm{W}$ and dips $55^{\circ}$ to $60^{\circ}$ north where it brings serpentine into fault contact with fanglomerate. The drainage of the alluvial fan is entrenched at the fault scarp, but it is not offset laterally. Vertical offset of the fan surface is about 1.2 meters. The fault may continue westward offshore near the coast for an additional $10 \mathrm{~km}$. At one promontory $5 \mathrm{~km}$ east of the western tip of the island, locally called Cerro Colorado, well-bedded brown calcite-cemented sandstone with shell debris and wood fragments alternating with laminated to thin-bedded gray green siltstone and silty shale (possibly correlated to the Cretaceous Valle Formation) is in fault contact with the ophiolitic complex of Rangin (1978).

Other upper Quaternary faults may be present on the islands, but, except for a fault that cuts fan material north of Cabo Tosco, none are as obvious as the Alcatraz fault.

The zone of moderate seismicity apparently does not continue northwest along the continental margin to the Cedros Deep (Ness et al., personal communication), although the residents of Cedros Island report earthquake activity (Kilmer, 1979). The fault in the Cedros Deep crossed by the Leg 63 track cuts the seafloor, sug- gesting that the zone of active faulting extends northwestward on the continental margin. Upper Cenozoic faulting, possibly as recent as Pleistocene, is reported on Cedros Island (Kilmer, 1979), and an upper Pliocene to Pleistocene marine terrace on Vizcaino Peninsula has been gently folded into a southeast-plunging syncline (Robinson, 1979). Thus it seems possible that the zone of active tectonism consists of a set of discontinuous, subparallel faults that extend along the western margin of southern Baja California from the continental slope south of Magdalena Bay northwest to Cedros Deep and Cedros Island.

\section{PETROLEUM POSSIBILITIES OF THE MAGDALENA FAN}

Gas chromatography aboard ship revealed the presence of hydrocarbons of higher boiling point at depths greater than 600 meters at Site $471 . C_{1} / C_{2}$ ratios were as low as 382 at 680 meters depth, although the total amount of gas in the cores was relatively small. Whelan and Hunt (this volume) found the highest levels of $\mathrm{C}_{4}-\mathrm{C}_{8}$ hydrocarbons they had ever measured in a DSDP core at 593 and 650 meters depth. They postulated that these hydrocarbons migrated from organic sediments heated to temperatures above $50^{\circ} \mathrm{C}$, as required for catagenic hydrocarbon generation. They suggest that the heat source may have been a diabase sill at 823 meters. Rullkötter and others (this volume), on the basis of huminite/vitrinite reflectance, suggest that kerogen maturity at Site 471 occurs at about 700 meters; the sediments themselves are more favorable for thermal generation of gas rather than oil. It seems likely, therefore, that Site 471 was in an updip position to trap hydrocarbons, probably gas, migrating from more deeply buried areas where temperatures were higher. Migration could have occurred along thin turbidite sand layers that are characteristic of the middle Miocene fan sequence.

Examination of the Glomar Challenger track shows that the fan sequence thickens northeastward to the foot of the continental escarpment, but reflections cannot be recognized at that level beneath the slope and shelf. A pronounced free-air gravity minimum is centered at the base of the escarpment (Huehn, 1977). Neglecting edge effects on the anomaly, the low-density sediments may extend farther northeast to the point where they are cut off by the right-lateral Tosco-Abreojos fault zone.

The turbidite sand layers at Site 471 are quartzo-feldspathic, relatively low in volcanic debris, and so they would be expected to increase in thickness northeastward toward their presumed source. Prospective areas for hydrocarbons, especially gas, would lie northeast of the site, possibly beneath the continental slope or shelf. Delineation of the deep horizons by CDP seismicreflection profiling would provide a better estimate of possible exploratory targets within the middle Miocene fan deposits.

\section{PALEOENVIRONMENTAL IMPLICATIONS}

One of the major objectives of Leg 63 was to delineate the history of the north Pacific eastern boundary current system by recovering relatively continuous 


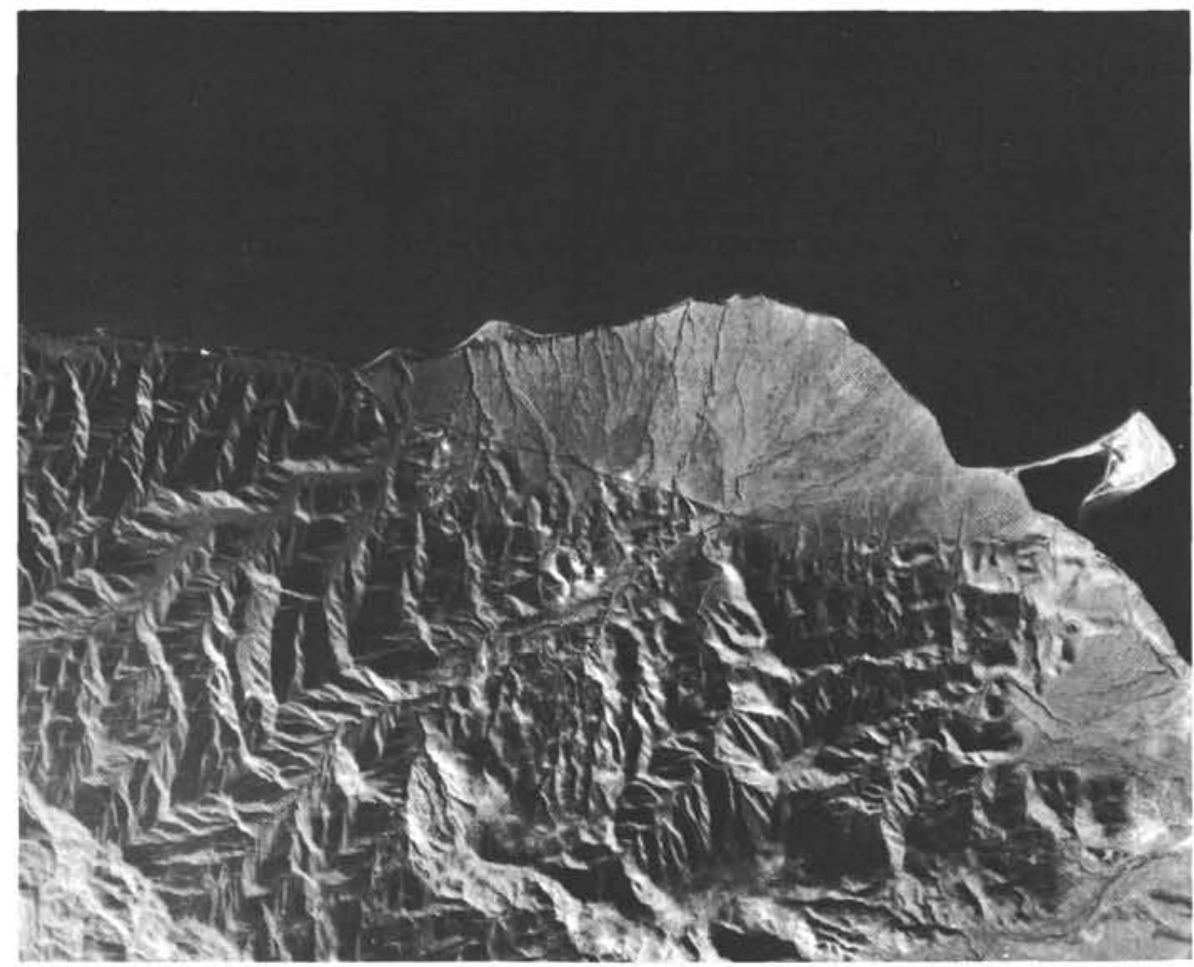

Figure 10. Vertical aerial photo of part of north coast of Santa Margarita Island showing Alcatraz fault cutting alluvial fan at Punta Cisne (cf., Fig. 9). (Straight coastline west of Punta Cisne may be controlled by westward extension of Alcatraz fault, labeled in Fig. 9.)

and well-preserved Neogene sequences along a northsouth transect under the track of the present-day California Current. Any oscillations in the configuration and intensity of the current system should have been preserved in the microfossil record. This objective could not be realized entirely, because of the generally poor preservation of fossils in sediments recovered during Leg 63. Dilution of pelagic facies due to high terrigenous input in parts of the section, diagenesis enhanced by high heat flow along the outer borderland sites, and erosional hiatuses severely limited the micropaleontological record of Leg 63.

Of all the sites drilled during Leg 63 , only Site 470 , near the Guadalupe Site for the Experimental Mohole of 1961, provides a relatively well-preserved Neogene microfossil record. Most sites contain numerous hiatuses (see Barron et al., this volume) and provide a patchy record at best. Calcareous nannoplankton provide the most consistent biostratigraphic record, even where other fossil groups have been severely altered by dissolution or diagenesis. Radiolarians and, to lesser degree, diatoms provide additional biostratigraphic control in the middle and late Miocene sequences (Wolfart, this volume; Barron, this volume). The record of planktonic foraminifers is particularly meager, useful mostly for the Pliocene part of some of the sections (Poore, this volume).

The sketchy paleoenvironmental conclusions based on the generally poor microfossil record of Leg 63 cores corroborate the earlier interpretations, based on the study of cores from DSDP Site 173 (off northern Cali- fornia) and on the study of Neogene sections in coastal California (Ingle 1973, 1980). Site 173 contains a record of major biofacies changes that corresponds to a series of climatic events within the California Current system (Ingle, 1973; Keller, 1978). In general, the late Oligocene to middle Miocene interval shows oscillations between warm-temperate and cool climates, with temperate conditions through most of the middle Miocene, followed by a major refrigeration in the late Miocene (Ingle, 1973). Site 173 shows a brief period of subtropical conditions in the latest Miocene, which was preceded by a relatively lengthy subarctic interval. Ingle's (1973) study shows that the Pliocene started with a brief period of decreased surface temperatures to subarctic levels, followed by a period of subtropical temperatures up to $45^{\circ} \mathrm{N}$ through the remainder of the early Pliocene. The late Pliocene shows climatic fluctuations that were followed by a sharp rise in the surface temperatures and the migration of subtropical biofacies to $40^{\circ} \mathrm{N}$ near the Pliocene/Pleistocene boundary (Ingle, 1973; Keller, 1978).

The record of Leg 63 sites indicates climatic trends that are similar to those at Site 173. The evidence provided by fossil groups suggest increasing water temperatures southward along the Leg 63 transect at any given time (Haq, Yeats, et al., 1979). Siliceous microplankton, however, best show the major pre-Quaternary fluctuations. For example, cool-water diatoms were common in the early late Miocene, which confirms the episode of late Miocene refrigeration noted by Ingle (1973). The nannofossil record at Site 470 indicates that 
the California Current system was stable and moderately warm during middle Miocene, unstable in late Miocene, and alternating between warm and cold phases in the Pliocene and Quaternary (Bukry, this volume). For the Pliocene interval, the planktonic foraminiferal record is also useful and indicates two northward excursions of warm-water fauna at about $4 \mathrm{Ma}$ and between 2.7 and $2.8 \mathrm{Ma}$ (Poore, this volume). These climatic events are similar to those delineated for Sites 173 and 310 (Ingle, 1973; Keller, 1978).

The diagenesis of microfossils reveals important clues to the thermal and burial histories of sediments. Downward in the sections, sediments rich in siliceous microfossils transform to porcelaneous claystones and then to opal-CT porcellanites; nannofossil clay and ooze change to chalk. These diagenetic trends are similar to those observed in the Neogene sediments in California and other places along the Pacific rim (Ingle, 1980).

The organic geochemical studies also give some clues about the sedimentary processes, productivity of surface waters, degree of oxygenation of bottom waters, and the diagenesis of sediments (see Simoneit et al., this volume). The organic material in sediments recovered during Leg 63 is predominantly marine in character, however, there is a substantial terrigenous input in the upper part of Site 467 and deeper part of Site 471 . The change from predominantly marine to a mixed marineterrestrial organic facies at Site 467 reflects an increased supply of terrigenous material in the late Pliocene (Simoneit et al., this volume). The middle Miocene highproductivity event that led to the deposition of the Monterey Formation (Ingle, 1980) is recorded as a marked upwelling event reflected in the middle Miocene total organic carbon maximum at Site 471 . A change in the deeper part of the section from a predominantly terrestrial organic facies to more marine facies in the shallower section nay be related to the change from deep-sea fan compiex to more pelagic sedimentation in the late Miocene.

\section{CONCLUSIONS}

The seven sites drilled during Leg 63 increased our information about the Miocene and more recent tectonic history of Baja and Alta California, although we did not gain as much information as had been anticipated. Sediment accumulation rates for the middle Miocene in the three borderland sites are similar to those in finegrained Monterey Shale of the same age onshore. The change upsection from uniform to more variable rates occurred in the late middle Miocene, about the same time as a major unconformity in the outer southern California borderland. An increase in sediment accumulation rates in the Pliocene at Site 467 may be related to an increase in onshore tectonic activity. Youngest sediments have a greatly reduced terrigenous component compared to older sediments, suggesting that the borderland sites were cut off from the continental sediment source by the formation of intervening borderland basins and ridges. Volcanic rocks are as young as late Miocene at Site 467 , as they are at several other localities in the borderland.

The age of oldest sediments directly overlying basalt is in agreement with the age predicted by isostatic subsidence curves at Sites 470 and 471 , but not at Site 469 , where the age-depth relationship predicts an age as much as 5 m.y. greater than observed. Perhaps Site 469 is affected by the vertical load of the adjacent continent and is thus too deep for its age.

At Site 471 , located on the Magdalena fan, we penetrated sediments $14.5 \pm 0.5 \mathrm{~m} . \mathrm{y}$. in age directly over basalt, several million years older than predicted by an eastward extrapolation of magnetic anomalies. Half the fan consists of middle Miocene strata, including turbidites, deposited at rates of $250 \mathrm{~m} / \mathrm{m}$.y. The overlying sediments do not include turbidites and were deposited at rates of 50 to $20 \mathrm{~m} / \mathrm{m}$.y. Possibly Site 471 was drilled on a trapped fragment of the Farallon plate, preserved when the rise crest west of the site ceased spreading, and a new spreading center formed southeast of the site. The thick fan deposits may have been deposited when the site was in the mouth of the Gulf of California, prior to right-lateral offset on the Tosco-Abreojos fault zone. The western margin of Baja California appears to be tectonically active today, on the basis of the young northeast-facing fault scarps observed on marine seismic profiles and on Santa Margarita Island. Hydrocarbons analyzed from Site 471 suggest that the middle Miocene turbidites of the Magdalena fan may contain gas northeast of Site 471 where the strata have undergone deeper burial.

Paleoenvironmentally, Leg 63 broke even less new ground than the tectonic conclusions described above. Prior to the cruise, we had hoped to be able to delineate the detailed history of the California Current system, to chart the climatic fluctuations associated with the oceanographic changes, and to correlate planktonic biostratigraphies with the benthic California stratigraphy with the help of recovered cores. The paleontological record of Leg 63 was severely limited by diagenetic alteration of microfossils enhanced by high heat flow along borderland sites, dilution by terrigenous material, and by numerous erosional hiatuses. The limited paleontological and organic geochemical studies serve only to confirm the broad climatic-oceanographic history of the area delineated in earlier studies.

\section{ACKNOWLEDGMENTS}

Many of the ideas presented here were tempered by lively debate among our colleagues on Leg 63, and our advocacy of certain interpretations does not necessarily meet with their approval. Our drilling plans were greatly aided by unpublished data made available to us by Jim Crouch and Jack Vedder of the U.S. Geological Survey (for the southern California borderland), Dick Couch and Gordon Ness of Oregon State University, Bill Normark of the U.S. Geological Survey (for the sites west of Baja California), and Jacqueline Mammerickx of Scripps Institution of Oceanography (for the mouth of the Gulf of California). The paper was reviewed by Gordon Ness, Bill Normark, and Jack Vedder. The outstanding co-operation and extra effort of the GMI crew of Leg 63 made it possible for us to drill one more site than anticipated, Site 472 , which added greatly to our understanding of the continental margin of the Californias. 


\section{REFERENCES}

Arnal, R. E., 1980. Comment on "Comparison of Miocene provincial foraminiferal stages to coccolith zones in the California Continental Borderland." Geology, 8:2-5.

Atwater, T., 1970. Implications of plate tectonics for the Cenozoic tectonic evolution of western North America. Geol. Soc. Am. Bull., 81:3513-3536.

Calderon R., G., 1978. A marine geophysical study of Vizcaino Bay and the continental margins of western Mexico between $27^{\circ}$ and $30^{\circ}$ North Latitude [Ph.D. thesis]. Oregon State University, Corvallis.

Chase, C. G., Menard, H. W., Larson, R. L., et al., 1970. History of sea-floor spreading west of Baja California. Geol. Soc. Am. Bull., 81:491-498.

Coperude, S. P., 1978. Geologic structure of the western continental margin of south central Baja California based on seismic and potential field data [M.S. thesis]. Oregon State University, Corvallis.

Crouch, J. K., 1979. Marine geology and tectonic evolution of the northwestern margin of the California Continental Borderland [Ph.D. thesis]. University of California, San Diego.

Crouch, J. K., and Bukry, D., 1979. Comparison of Miocene provincial foraminiferal stages to coccolith zones in the California Continental Borderland. Geology, 7:211-215.

Crouch, J. K., Holmes, M. L., McCulloh, T. H., et al., 1978. Multichannel seismic reflection and sonobuoy refraction data in the outer southern California borderland. U.S. Geol. Survey OpenFile Rep. 78-706.

Gastil, R. G., Krummenacher, D., and Minch, J. A., 1979. The record of Cenozoic volcanism around the Gulf of California. Geol. Soc. Am. Bull., 90:839-857.

Haq, B. U., Yeats, R. S., Barron, J. A., et al., 1979. Eastern Pacific boundary currents. Geotimes, 24(4):30-31.

Huehn, B., 1977. Crustal structure of the Baja peninsula between latitudes $22^{\circ} \mathrm{N}$ and $25^{\circ} \mathrm{N}$ [M.S. Thesis]. Oregon State University, Corvallis.

Ingle, J. C., Jr., 1973. Summary comments on Neogene biostratigraphy, physical stratigraphy, and paleo-oceanography in the marginal northeastern Pacific Ocean.In Kulm, L. D., von Huene, R., et al., Init. Repts. DSDP, 18: Washington (U.S. Govt. Printing Office), 949-960.

1980. Cenozoic paleobathymetry and depositional history of selected sequences within the southern California Continental Borderland. Cushman Foundation, Spec. Publ., 19:163-195.

Keller, G., 1978. Late Neogene planktonic foraminiferal biostratigraphy and paleoceanography of the northeastern Pacific: evidence from DSDP Sites 173 and 310 at the North Pacific front. J. Foram. Res., 8:208-224.

Kilmer, F. H., 1979. A geological sketch of Cedros Island, Baja California, Mexico. In Abbott, P. L., and Gastil, R. G., (Eds.), Baja
California Geology. Field Guides and Papers: San Diego State University, San Diego, California (Dept. Geological Sciences), pp. 11-28.

Krause, D. C., 1965. Tectonics, bathymetry, and geomagnetism of the southern continental Borderland west of Baja California, Mexico. Geol. Soc. Am. Bull., 76:617-650.

Krueger, H. W., 1964. K-Ar age of basalt cored in the Mohole Project (Guadalupe Site). J. Geophys. Res., 69:1155-1156.

Menard, H. W., 1978. Fragmentation of the Farallon plate by pivoting subduction. J. Geol., 86:99-110.

Moore, D. G., 1969. Reflection profiling studies of the California Continental Borderland: structure and Quaternary turbidite basins. Geol. Soc. Am. Spec. Pap. 107.

Ness, G. E., Levi, S., and Couch, R. W., 1980. Marine magnetic anomaly timescales for the Cenozoic and late Cretaceous-a precis, critique and synthesis. Rev. Geophys. Space Phys., 18:753770.

Rangin, C., 1978. Speculative model of Mesozoic geodynamics, central Baja California to northeastern Sonora (Mexico). In Howell, D. G., and McDougall, K. A., (Eds.), Mesozoic Paleogeography of the Western United States: Pacific Section, Soc. Econ. Paleontologists and Mineralogists, Pacific Coast Paleogeography Symposium 2, pp. 85-106.

Robinson, J. W., 1979. Structure and stratigraphy of the northern Vizcaino Peninsula with a note on a Miocene reconstruction of the peninsula. In Abbott, P. L., and Gastil, R. G., (Eds)., Baja California Geology, Field Guides and Papers: San Diego State University, San Diego, California (Dept. Geological Sciences), pp. 77-82, map pp. 5-7.

Sclater, J. G., Anderson, R. N., and Bell, M. L., 1971. Elevation of ridges and the evolution of the central eastern Pacific. J. Geophys. Res., 76:7888-7915.

Spencer, J. E., and Normark, W. R., 1979. Tosco-Abreojos fault zone: A Neogene transform plate boundary within the Pacific margin of southern Baja California, Mexico. Geology, 7:554-557.

Sykes, L. R., 1968. Seismological evidence for transform faults, sea floor spreading, and continental drift. In Phinney, R. A., (Ed.), The History of the Earth's Crust: Princeton, New Jersey (Princeton University Press), pp. 120-150.

Turcotte, D. L., and Ahern, J. L., 1977. On the thermal and subsidence history of sedimentary basins. J. Geophys. Res., 82:37623766.

von Huene, R., and Kulm., L. D., 1973. Tectonic Summary of Leg 18: In Kulm, L. D., von Huene, R., et al., Init. Repts. DSDP, 18: Washington (U.S. Govt. Printing Office), 961-976.

Yeats, R. S., 1968. Southern California structure, sea-floor spreading, and history of the Pacific basin. Geol. Soc. Am. Bull., 79: 1693-1702.

1978. Neogene acceleration of subsidence rates in southern California. Geology, 6:456-460. 